비외상성 급성 복부 통증 환자에게 시행한 복부 전산화단층촬 영과 복부 단순 촬영의 적정성 비교

송정흡 ${ }^{1}$, 염헌규 ${ }^{2}$

1경북대학교병원 공공보건사업실, ${ }^{2 ㄱ ㅕ ㅇ ㅂ ㅜ ㄱ ㄷ ㅐ ㅎ ㅏ ㄱ ㄱ ㅛ ㅂ ㅕ ㅇ ㅇ ㅝ ㄴ ~ ㅇ ㅕ ㅇ ㅅ ㅏ ㅇ ㅇ ㅢ ㅎ ㅏ ㄱ ㄱ ㅘ ~}$

\title{
The Comparison of Appropriateness of Abdominal Computed Tomog- raphy (CT) and Abdominal Radiography Imaging Modality for Patients with Acute Nontraumatic Abdominal Pain
}

\section{Jung-Hup Song', Hun-Kyu Ryeom²}

1 Public Health Service, Kyungpook National University Hospital, Daegu, Korea,

${ }^{2}$ Department of Radiology, Kyungpook National University Hospital, Daegu, Korea 
Purpose: To compare the Appropriateness of abdominal CT to abdominal radiography as an imaging modality in terms of the diagnostic value, medical costs and decision making times for patients presented to the emergency department with nontraumatic abdominal pain.

Methods: This study used the records of 530 cases presented to the emergency department(ED) with nontraumatic abdominal pain from February to March 2012. Imaging modalities were categorized into abdominal radiography and CT (radiography first or CT first) or radiography alone or CT alone. The diagnostic value, total medical costs and effect on decision making time of the each imaging modalities were compared. Especially, in retrospective review, to evaluate the predictability of the abdominal radiography, alit was assumed that all the 530 cases performed that exam as initial imaging.

Results: Among 530 cases, 255 cases underwent abdominal radiography only, 28 cases underwent abdominal CT only and the remnant 247 cases underwent abdominal CT with plain abdominal radiography. The diagnostic value was higher in the cases with abdominal CT $(268 / 275,97.5 \%)$ than in the cases with plain abdominal radiography $(19 / 255,7.5 \%)$. The number of cases predicted by abdominal radiography only as initial imaging were 39/530 (7.4\%).

In cases where the patients performed the abdominal CT as the first imaging modality thereby omitting the abdominal radiography, the total diagnostic imaging fee was lower than in cases with plain abdominal radiography first followed by the abdominal CT (277,140 vs. 284,226(mean, Korean Won)). Although diagnostic value of the plain abdominal radiography as first imaging modality was lower than the abdominal CT, Decision making time, average duration of hospital stay was longer and the total medical costs was higher than abdominal CT.

Conclusion: As an imaging modality in the ED for patients with acute nontraumatic abdominal pain, plain abdominal radiography is an avoidable procedure when viewed in terms of the diagnostic value and total medical costs and decision making times comparing with abdominal CT.

Key words: Computed tomography, Appropriateness studies, Abdomen, Emergency department 


\section{I. 서론}

비외상성 급성 복부 통증은 응급실을 내원하는 환자의 가 장 흔한 원인 중 하나이며 이러한 급성 복부 통증을 일으킬 수 있는 원인 질환은 매우 다양하다[1-4]. 복부 통증을 주 소로 하는 환자가 응급실에 내원하면 응급의학과 의사의 문진과 신체검사를 시행한 후, 추가로 영상검사가 필요하 다고 판단되었을 때, 대부분의 경우 복부 단순 촬영이 영상 검사로 먼저 시행된다. 일반적으로 진단적 정확도 측면에 서 복부 전산화 단층 촬영(Computed tomography; CT) 이 복부 단순 촬영보다 우월하다는 것이 잘 알려져 있고, 촬영 건수도 증가하고 있다[5]. 복부 CT는 임상 의사의 추 정 진단에 대한 정확한 확인을 통해 진단에 대한 자신감을 올려주고 응급의료환경에서 환자의 분류와 관리에 효율적 이라고 알려져 있다[6]. 그러나 부적절한 CT 촬영 시 발생 할 비용과 방사선 노출 위험에 대한 우려가 높아서[7], 첫 번째 영상 검사는 방사선 노출과 비용의 부담이 적은 복부 단순 촬영을 시행하는 것이 일반적이다.

응급의료에 관한 법률 제 2 조 '응급환자' 의 정의와 달 리 최근 응급 환자의 정의는 의사가 판단해서 정하는 것 이 아니라 환자나 환자의 보호자가 응급이라고 생각하는 한 응급이 아님이 의학적으로 밝혀지기 전까지는 응급으 로 간주하여야 한다는 것이 일반적으로 받아들여지고 있 다[8]. 또한 환자나 보호자는 응급실 방문 시 신속한 진단 또는 환자 분류로 최단 시간 내 처리 즉, 처치나 치료 혹 은 전원에 대한 빠른 해결을 위한 요구도가 높아지고 있 다. 비외상성 급성 복부 통증을 호소해서 응급실을 방문 한 환자에게 병원에서 가장 먼저 해야 하는 것은 급성 복 증(acute abdomen: 즉시 처치가 필요한 경우 그렇지 않 으면 위험한 상태)을 빨리 감별해서 그에 따른 처치를 하 는 것이다.

현재의 건강보험 제도에서도 응급환자의 CT를 비롯한 영상검사는 일반적으로 급여로 인정해준다. 응급의료의 개념 및 건강보험 제도의 변화에도 실제 상급종합병원 응 급실에서는 급성 복통 환자의 경우 복부 단순 촬영 결과 를 보고 필요시에 CT 검사를 추가로 촬영하는 경우가 많
다. 응급의학과 의사의 판단에 $\mathrm{CT}$ 검사가 바로 필요하다 고 생각되는 경우에도 $\mathrm{CT}$ 단독촬영보다는 관행적으로 복 부 단순 촬영과 복부 $\mathrm{CT}$ 두 가지 검사 모두를 시행하는 경우가 많다. 관행적으로 이 두 가지 검사 모두를 시행하 는 것이 환자나 건강보험 재정에 유리한 방법인가 의문이 생긴다.

이에 저자들은 응급실 진료 프로세스를 개선하기 위해서 ECRS (Elimination, Combine, Rearrange, Simplify) 기법[9] 중 재정렬과 제거방법을 이용하여 영상검사가 필 요했던 비외상성 급성 복부 통증 환자를 후향적으로 분석 하여 단순 복부 일반촬영과 $\mathrm{CT}$ 검사의 촬영 순서 변경과 촬영 제거(복부 일반 촬영과 $\mathrm{CT}$ 촬영의 순서를 바꾸거나 제거하여 그 효과 분석)를 통하여 영상검사의 진단적 가치 응급 환자의 신속한 구분 가능성과 진단 가능 범위를 분석 하여 비용-효과적인 영상획득장비(modality) 찾기 위해서 본 연구를 하였다.

\section{II. 연구방법}

본 연구의 대상 병원은 권역응급의료센터 이고 허가병상 수는 32병상, 일평균내원환자수는 137.1 명인 상급종합병 원이었으며 임상시험심의위원회(Institutional Review Board)에서 후향적인 연구로서 환자 동의서 면제를 받았 다. 2012년 2월부터 3월까지 1개월간 본원 응급실에 내 원한 비외상성 급성 복부 통증 환자 중 내원 당일 의사 진 찰 후 추가로 영상 검사가 필요하다고 판단되어 영상 검사 를 시행한 총 530명의 환자를 대상으로 하였다.

변수는 응급실 내원시간, 영상검사 첫번째, 두번째 처방 명 및 시간과 진단명, 영상처방시행시간, 총진료비 등이 었다.

PACS 모니터를 이용하여 7년 경력의 복부 영상 전문의 와 한 명의 전공의가 환자의 영상 소견을 협의 하에 분석 하였고, 연구에 포함된 환자들의 전자의무기록을 후향적 으로 조사하여 최종 진단, 영상 검사의 종류와 시행 순서, 검사 소요시간, 검사 비용 및 즉시 판독을 가정했을 때의 환자 분류까지 추정된 영상 비용 등을 분석하였다. 
응급실에서 시행한 영상검사방법은 복부 단순 촬영만 시 행한 경우, 그리고 복부 전산화 단층 촬영과 복부 단순 촬 영을 모두 시행한 경우, 그리고 전산화 단층 촬영만 시행 한 경우로 나누었고, 두 검사 모두 시행한 경우에는 전산 화 단층촬영을 먼저 시행한 경우와 복부 단순 촬영을 먼저 시행한 경우로 나누어 분석하였다. 복부 단순 촬영은 기 립/앙와위 촬영과 $\mathrm{KUB}$ 처방으로 촬영한 영상이 포함되었 고 복부 전산화 단층 촬영은 복부 CT, 복부 dynamic CT (liver), 복부-골반 dynamic CT, 골반 CT로 처방된 영상 을 포함했다.

복부 단순 촬영은 RADSPEED (Shimadzu, Kyoto, Japan)장비를 이용하여 시행하였고 결과는 각각 정상과 비 정상으로 분류하였으며 당직 전공의 3 년차 이상의 판독을 기준으로 하였다.

정상 소견은 복강 내 비정상적인 장외 공기 또는 비정상 적으로 늘어난 장, 돌과 같은 물질들로 인해 비정상적으로 증가한 음영 등이 없이 비특이적인 장내 공기들과 정상적 인 연조직음영들로 이루어진 상태로 정의하였다. 비정상 소견은 위에서 언급한 대로 비정상적인 복강내 장외 공기 가 있거나 비정상적으로 늘어난 장들이 보이는 경우, 돌과 같은 물질들로 인해 비정상적인 증가된 음영이 있는 경우 등 정상으로 볼 수 없어 추가적인 검사가 필요하거나 추가 적인 처치가 필요한 상태의 영상으로 정의하였다.

복부 전산화 단층 촬영은 Aquilion 64 (Toshibam Tokyo, Japan)장비를 이용하여 $5 \mathrm{~mm}$ 두께 단위로 촬영하였 고 조영 증강 없이 시행하거나, 조영 증강 시 정맥을 통하 여 Ultravist 370 (iopromide, Bayer Korea) 조영제를 주입하여 사용하였다.

복부 $\mathrm{CT}$ 의 판독을 좀 더 세분화하여 비교하였고 복부 $\mathrm{CT}$ 의 판독 또한 영상의학과 3 년차 이상의 당직 전공의 판 독을 기준으로 하였다. 복부 전산화 단층촬영 판독 결과 분류는 아래 질환 중 어떤 질환에도 속하지 않고 비특이적 인 양상만 보이는 경우를 정상소견으로 분류하였다. 질환 은 복부 대동맥 박리, 급성 충수돌기염, 급성 간염, 급성위 장관염, 급성신우신염, 담관 및 담낭의 담석관련 질환, 위 장관 허혈성 질환, 변비, 게실염, 간농양, 선천성 거대결
장, 염증성 장질환, 장중첩증, 간경변증, 악성 종양, 난소 낭종, 췌장염, 범복막염, 골반 염증성 질환, 신부전, 장폐 색, 비뇨기 결석질환, 자궁근종 등이었다.

환자 분류 시간은 응급실 방문에서 응급의학과의 환자 분류를 통해 임상 과에 전과 될 때까지의 시간이라고 할 수 있다. 그러나 후향적 연구로 기록이 정확하지 않을 수 있고 응급실 접수 후 대기 시간 및 문진, 심전도, 혈액검사 등의 기타 소요 시간, 각 과의 사정 등 변수가 너무 많아 서, 이 연구에서는 각각의 검사를 시행 완료 후 바로 판독 하였다고 가정하고, 접수 후 복부 단순 촬영과 복부 CT 중 최종 검사 종료까지의 소요 시간 간격을 환자 분류 시간에 영향을 미치는 요인으로 간주하여 비교하였다.

비용 분석은 환자의 영상 검사 최종 비용을 조사하였으 며 단순 복부 촬영을 먼저 시행한 경우와 CT를 먼저 시행 한 경우로 나누고 영상의학과 의사가 바로 판독했을 경우 를 가정하여 환자 분류 가능 시점까지의 소요 비용을 추정 하여 비교하였다.

최종 퇴원 시 진단명은 병원 전자 의무기록에 기록된 퇴 원 시 진단명으로 정의하였고 이 최종진단과 복부 전산화 단층촬영 판독지의 추정진단 결과를 비교하여 일치율을 진단 예측의 정확도로 정의하였다. 후향적 조사에서 최초 영상 진단 정확도는 530 명 환자의 최초 영상검사를 기준 으로 분석하였다.

\section{III. 결과}

총 530 명의 환자 중 275 명(51.9\%)의 환자가 복부 CT 를 시행하였고 그중 205명(38.7\%)의 환자는 복부 단순 촬 영 후 복부 CT를 시행하였고고 42 명(7.9\%)의 환자는 복 부 CT를 먼저 시행 후 복부 단순촬영을 시행하였으며 28 명(5.3\%)의 환자는 복부 CT만 시행하였다. 나머지 255명 (48.1\%)의 환자는 복부 단순촬영만 시행하였다. 남녀간에 차이는 없었으나 연령별에는 유의한 차이가 있었다(Table 1). 또한 복부 단순촬영만 시행한 255명중 31명(12.1\%)은 입 원하여 병동에서 결국 CT를 찍은 것으로 조사되었지만, 우 리 연구의 응급실 검사 건수에는 포함시키지 않았다. 


\section{Original Articles}

Table 1. The distribution of modality by age and sex

(unit :\%)

\begin{tabular}{|c|c|c|c|c|}
\hline Variable & $\begin{array}{l}\text { Abdominal CT at first, followed } \\
\text { by abdominal radiography }\end{array}$ & $\begin{array}{l}\text { Abdominal radiography at first, } \\
\text { followed by abdominal CT }\end{array}$ & Abdominal CT only & Abdominal radiography only \\
\hline \multicolumn{5}{|l|}{ sex } \\
\hline Male & $25(59.5)$ & $102(49.8)$ & $16(57.1)$ & $126(49.4)$ \\
\hline Female & $17(40.5)$ & $103(50.2)$ & $12(42.9)$ & $128(50.64)$ \\
\hline \multicolumn{5}{|l|}{ age* } \\
\hline$\geq 20$ & $12(28.5)$ & $24(11.7)$ & $4(14.3)$ & $92(36.1)$ \\
\hline $21-40$ & $10(23.8)$ & 40 (19.6) & $5(17.8)$ & $44(17.3)$ \\
\hline $41-60$ & $10(23.8)$ & $61(29.7)$ & $9(32.2)$ & $56(21.9)$ \\
\hline$\leq 61$ & $10(23.8)$ & $80(39.0)$ & $10(35.7)$ & $63(24.7)$ \\
\hline total & $42(100.0)$ & $205(100.0)$ & $28(100.0)$ & $255(100.0)$ \\
\hline
\end{tabular}

* p, 0.01

복부 단순촬영만 시행한 255 명의 환자 중 오직 24 명복 부 단순 촬영만 시행한 255 명의 환자 중 24명(9.4\%)이 비정상 소견으로 판독되었다. 비정상 소견으로 판독된 내
용은 변비(7명), 장폐색(9명), 장마비(3명), 기복증(5명) 이었으며 나머지 231명(90.5\%)은 정상소견으로 판독되 었다(Table 2).

Table 2. The Result of simple abdomen radiology in 255 cases

\begin{tabular}{llr}
\hline diseased predictable & & $\mathrm{N}(\%)$ \\
\hline & constipation & $7(2.7)$ \\
positive & bowel obstruction & $9(3.5)$ \\
& ileus & $3(1.2)$ \\
negative & negative & 5(2.0) \\
total & & 231(90.6) \\
\hline
\end{tabular}


반면 복부 전산화단층촬영을 시행한 275 명의 환자 중 정 상 소견은 24명(8.7\%)이었고 나머지 251명(91.3\%)은 특 정한 추정 진단이 붙은 비정상 소견이었다. 비정상으로 판 독 된 진단명은 다음과 같다. 복부대동맥 박리(1명, $0.4 \%)$, 급성 충수돌기염(15명, $5.5 \%$ ), 급성 간염(1명, $0.4 \%)$, 급 성 위장관염(94명, $34.2 \%$ ), 급성신우신염(3명, $1.1 \%)$, 담 관 및 담낭의 담석관련 질환(34명, 23.6\%), 위장관 허혈 성 질환(3명, $1.1 \%)$, 변비(11명, $4 \%$ ), 게실염(1명, $0.4 \%$ ), 간농양(2명, $0.7 \%)$, 선천성 거대결장( 2 명, $0.7 \%)$, 염증성 장질환(2명, $0.7 \%)$, 장중첩증(3명, $1.1 \%)$, 간경변증(9명,
$3.3 \%)$, 악성 종양(23명, 8.3\%), 난소 낭종(4명, $1.5 \%)$, 췌 장염(10명, $3.6 \%$ ), 범복막염(5명, $1.8 \%$ ), 골반 염증성 질 환(7명,2.6\%), 장폐색(11명, 4.8\%), 비뇨기 결석질환(7명, $2.6 \%)$, 자궁근종(3명, $1.1 \%$ ) 이었다.

복부 CT를 시행한 275 명의 증례 중 268 명의 증례에서 최초 영상 판독과 최종 진단이 일치하여 진단의 예측율이 97.5\%였다. 530명의 증례를 최종진단명과 비교했을 때 17 명 증례가 정상 소견이었으며 7 명(2.5\%)의 증례, 즉, 4 명의 신부전 환자와 3 명의 과민성 장 증후군 환자에서만 복 부 CT촬영으로 최종 진단을 예측하지 못하였다(Table 3).

Table 3. The number of each CT interpretation and final discharge diagnosis among 530 cases

\begin{tabular}{|c|c|c|c|}
\hline Diagnosis & $\begin{array}{l}\text { Interpretation of CT scan } \\
\text { performed in ED }\end{array}$ & $\begin{array}{c}\text { Probability } \\
\text { (Correct CT diagnosis performed in ED) }\end{array}$ & $\begin{array}{l}\text { Final discharge diagnosis } \\
\text { [by imaging study (performed in ED } \\
\text { and wards) plus clinical study] }\end{array}$ \\
\hline Abdominal aortic aneurysm & $1(0.4)$ & $1 / 1$ & $2(0.4)$ \\
\hline Acute appendicitis & $15(5.5 \%)$ & $15 / 15$ & $30(5.7)$ \\
\hline Acute hepatitis & $1(0.4 \%)$ & $1 / 1$ & $3(0.6)$ \\
\hline Acute gastroenteritis & $94(34.2 \%)$ & $94 / 94$ & $190(35.8)$ \\
\hline Acute pyelonephritis & $3(1.1 \%)$ & $3 / 3$ & $6(1.1)$ \\
\hline Biliary stone disease & $34(23.6 \%)$ & $34 / 34$ & $65(12.3)$ \\
\hline Bowel ischemia & $3(1.1 \%)$ & $3 / 3$ & $6(1.1)$ \\
\hline Constipation & $11(4 \%)$ & $11 / 11$ & $22(4.2)$ \\
\hline Diverticulitis & $1(0.4 \%)$ & $1 / 1$ & $3(0.6)$ \\
\hline Hepatic abscess & $2(0.7 \%)$ & $2 / 2$ & $4(0.8)$ \\
\hline Hirschprung's disease & $2(0.7 \%)$ & $2 / 2$ & $4(0.8)$ \\
\hline Irritable bowel syndrome & $0(0 \%)$ & $0 / 3$ & $3(0.6)$ \\
\hline Inflammtory bowel disease & $2(0.7 \%)$ & $2 / 2$ & $7(1.3)$ \\
\hline Intussusception & $3(1.1 \%)$ & & $5(0.9)$ \\
\hline Liver cirrhosis & $9(3.3 \%)$ & $3 / 3$ & $18(3.4)$ \\
\hline Malignancy & $23(8.3 \%)$ & $23 / 23$ & $45(8.5)$ \\
\hline Ovarian cyst & $4(1.5 \%)$ & $4 / 4$ & $8(1.5)$ \\
\hline Pancreatitis & $10(3.6 \%)$ & $10 / 10$ & $20(3.8)$ \\
\hline Panperitonitis & $5(1.8 \%)$ & $5 / 5$ & $10(1.9)$ \\
\hline Pelvic inflammatory disease & $7(2.6 \%)$ & $7 / 7$ & $14(2.6)$ \\
\hline Renal failure & $0(0 \%)$ & $0 / 4$ & $4(0.8)$ \\
\hline Small bowel obstruction & $11(4.8 \%)$ & $11 / 11$ & $23(4.3)$ \\
\hline Urinary stone & $7(2.6 \%)$ & $7 / 7$ & $14(2.6)$ \\
\hline Uterine myoma & $3(1.1 \%)$ & $3 / 3$ & $7(1.3)$ \\
\hline Negative & $24(8.7 \%)$ & $24 / 24$ & $17(3.2)$ \\
\hline Total & $275(100)$ & $268 / 275(97.5 \%)$ & $530(100)$ \\
\hline
\end{tabular}




\section{Original Articles}

총 530명의 환자를 후향적으로 조사할 때 모든 환자가 첫 번째 영상 검사로 복부 단순 촬영을 했다고 가정하였을 때, 진단 예측은 39명(7.4\%)의 증례만 예측할 수 있었고, 나머 지 491명(92.6\%)의 증례는 복부 단순 촬영만으로는 진단 에 도움이 되지 않아서 추가적인 복부 전산화 단층 촬영이 필요하였다(Table 4).

응급실에서 진단에 필요한 영상검사 비용은 환자유형별 로 가산금이 달라 질 수 있어서 선택진료비와 시간 및 종 별가산율이 포함된 총진료비로 계산하였다. 복부단순촬
영 시행 후 복부 CT를 시행하였을 때는 총 비용(총진료 비)이 평균284,230원이었으며 복부 CT만 시행하였을 경 우에는 평균(총진료비) 265,520 원이었다(Table 5).

응급실에서 두 가지 영상검사 모두를 시행한 경우, 조사 했다. 복부 전산화단층촬영을 먼저 촬영한 뒤 복부 단순촬 영을 시핸 한 42 명의 환자에서 검사 사이의 평균 시간 간 격이 $76.17 \pm 140.87$ 분이었고 복부 단순촬영을 먼저 시행 한 뒤 복부 전산화 단층촬영을 시행한 205 명의 환자군에서 는 $106.62 \pm 121.69$ 분이었다.

Table 4. Predictable versus unpredictable cases that can diagnose only by abdominal radiography, when compared with final diagnosis

\begin{tabular}{ccc}
\hline Groups of patients & $\begin{array}{c}\text { Predictable cases only by } \\
\text { abdominal radiography (\%) }\end{array}$ & $\begin{array}{c}\text { Unpredictable cases only by } \\
\text { abdominal radiography (\%) }\end{array}$ \\
\hline $\begin{array}{c}\text { Patients who performed } \\
\text { Abdominal radiography only } \\
\text { Patients who performed } \\
\text { abdominal CT only }\end{array}$ & $19(7.5)$ & $236(92.5)$ \\
$\begin{array}{c}\text { Patients who performed both of } \\
\text { abdominal CT and abdominal radiography }\end{array}$ & $2(7.2)$ & $26(92.8)$ \\
\hline Total & $18(7.3)$ & $229(92.7)$ \\
\hline
\end{tabular}

Table 5. Radiological Imaging Costs and total mediacal costs in Emergency Department

\begin{tabular}{|c|c|c|c|c|}
\hline Modality & Cost & $\begin{array}{l}\text { Total medical costs } \\
\text { (Korean Won) }\end{array}$ & $\begin{array}{l}\text { Imaging costs for CT } \\
\text { (Korean Won) }\end{array}$ & $\begin{array}{l}\text { Imaging costs for abdominal } \\
\text { radiography } \\
\text { (Korean Won) }\end{array}$ \\
\hline $\begin{array}{l}\text { Patients who underwent abdominal } \\
\text { radiography first followed by abdominal CT } \\
\qquad(\mathrm{n}=205)\end{array}$ & Mean & $284,230 \pm 40,690$ & $247,290 \pm 35,480$ & $12,250 \pm 8,220$ \\
\hline $\begin{array}{l}\text { Patients who underwent abdominal CT only } \\
\qquad(\mathrm{n}=28)\end{array}$ & Mean & $265,520 \pm 52,130$ & $240,580 \pm 43,650$ & - \\
\hline $\begin{array}{l}\text { Patients who underwent abdominal } \\
\text { radiography only } \\
(\mathrm{n}=255)\end{array}$ & Mean & $12,220 \pm 19,350$ & - & $11,020 \pm 2,820$ \\
\hline
\end{tabular}




\section{IV. 고 찰}

비외상성 급성 복부 통증은 상급종합병원 응급실에 내원 하는 환자들이 호소하는 가장 흔한 증상 중 하나이다[10]. 급성 복부 통증을 호소할 수 있는 질환의 범위는 다양하다. 단순 변비에서부터 응급수술이 필요한 범복막염에 이르고, 중증도도 매우 다양하다[11].

이러한 현실 속에서 응급 상태에 대한 용어 정의는 점차 환자 위주로 바뀌고 있다(Patient oriented definition). 미국 병원협회(American Hospital Association)에서는 '응급상태(emergency)'를 “환자 본인이나, 가족, 혹은 병 원으로 이송할 책임이 있는 자가 느끼기에 즉시 의학적인 치료가 필요한 상태로 의료인이 판단하기에 환자의 생명과 건강이 위험하다고 결정될 때까지의 상태"로 정의하고 있 다. 이 정의에 따르면 환자 본인이나 보호자 등이 느끼기에 의학적인 치료가 필요하다고 생각하면 의료인은 환자가 응 급인지 아닌지를 의학적인 지식과 검사 결과에 따라 즉시 판단을 내려야 한다. 이 경우 객관적이고 합리적인 판단에 따라 환자의 의사결정을 내리기 전까지는 잠정적인 응급상 태라고 봐야 한다. 증상을 호소하는 환자에 대해서는 정확 하고 신속하게 진단/분류를 하고 그에 따라 적절한 진료가 이루어져야 한다. 이 때 임상 의사의 진찰과 문진, 그리고 영상 검사가 필요하다. 특히 영상 검사의 뒷받침이 잘 되면 임상 의사는 추정 진단에 대해서 좀 더 강한 확신을 가지고 신속하게 환자를 관리하고 진료 할 수 있을 것이다.

현재 국민건강보험제도에서 임상 의사가 영상검사가 필 요하다고 판단된다면, 복부 단순촬영이나 복부 CT는 건강 보험이 적용된다. 이러한 현실과 맞물려서 실제 응급의료 현장에서 복부 단순 촬영은 응급실로 내원한 급성 복부 통 증 환자에서 거의 관행적으로 시행된다. 하지만 실제 많은 수의 증례에서 복부 단순 촬영만으로는 특정 병변의 발견 이나 정확한 질병 진단이 어려운 경우가 많다. 기복증과 같 이 복부 단순촬영만으로 문제를 발견 할 수 있는 경우이거 나 즉시 개복이 필요한 질환이라고 하더라도 증상을 일으 킨 원인 병변을 찾기 위해서는 다시 복부 CT를 시행하는 경우가 많다. 이렇듯 복부 CT가 복부 단순 촬영에 비해서
민감도와 특이도가 높고 진단적 우수성이 우위에 있다는 것은 이전 연구들[4-5,12]에서부터 꾸준히 제기 되어 일 반적으로 널리 받아들여진 사실이다. 상급종합병원의 응급 의료현장에서는 복부 CT의 상대적 높은 비용과 방사선 노 출 위험 등의 이유로 복부 단순 촬영을 관행적으로 첫 번째 영상검사로 시행하고 있다[4].

후향적 연구의 특성상, 첫 영상 검사로 복부 단순 촬영 혹 은 복부 CT를 시행한 이유를 직접 조사하기 어려웠다. 이 러한 상황에서, 급성 복통이 강하게 의심되는 상황, 또는 환자의 증상이 비특이적이고 임상적으로 중증으로 판단되 지 않아 급성복증이 배제되고 더이상 응급상황이 아니라 고 결정내릴 수 있을 만한 상황이라면 단순 촬영이 우선적 으로 시행되는 것이 타당하다. 이 연구에서 보듯이 CT만 찍은 환자는 530 명 중 28 명(5.3\%)에 불과하였고 나머지 502명(94.7\%)은 모두 단순촬영을 시행하였으며 그 중에서 도 460명(87.8\%)는 단순촬영을 최초의 영상검사로 시행하 였다. 복부 단순 촬영만 시행한 255 명 중 31 명은 추후 입 원하여 CT를 시행한 것으로 나타났지만 대다수 즉 224 명 (87.9\%)은 영상검사를 종료하였다. 비용-효과적인 면에서 적절한 판단이 이루어졌다고 보여진다.

$\mathrm{CT}$ 적응증은 고열과 함께 혈액검사소견상 염증 수치가 상승되어 있는 경우, 환자의 활력 징후가 안정적이지 않을 경우, 국소적 압통이나 반발통이 있어서 국소 병변을 찾아 야 하지만 추정 진단이 범복막염이나 장폐색 등 단순촬영 에서 진단이 가능한 것이 아닐 경우(예. 충수돌기염, 게실 염, 담낭염 등)등 이다. 이러한 적응증에 해당되어 검사 처 방을 낼 때 복부 단순촬영이 진단에 도움이 되지 않을 가 능성이 많다는 것을 임상 의사도 알고 있지만, 어차피 입원 이 필요한 환자임을 알고 이후 복부 단순 촬영 추적검사를 위한 기저검사로 복부 단순촬영을 하는 경우, 또는 관행적 으로 복부 단순 촬영 처방을 내는 경우가 있다. 하지만 복 부 CT만으로도 충분히 복부 단순촬영을 대체할 수 있고 복 부 단순촬영에서 어떻게 보일지도 추정할 수 있기 때문에 복부 단순 촬영은 시행하지 않아도 되는 검사가 된다. 다만 상급종합병원 응급진료 특수성을 감안한다면, 복부 CT를 바로 찍는 적응증을 좀 더 넓게 적용하여 숨어 있을지 모르 
는 병변 발견의 진단율을 높이는 것이 오진의 위험성을 낮 추는 데에도 도움이 될 수 있을 것으로 판단된다. 응급 상 태가 아님이 배제될 때 까지는 응급으로 가정하고 빠른 처 치를 위해 복부 CT를 우선적으로 시행하는 것이 고려되어 야 할 것이다. 본 연구에서는 비용적인 측면에서도 차이를 발견 할 수 있었고 필연적인 결과이지만 복부 단순 촬영을 함께 시행한 경우보다 복부 CT만 시행한 환자 군에서 의료 비가 감소하였다. 특정 적응증이 확인 된 환자만이라도 불 필요한 복부 단순 촬영을 줄일 수 있다면 의료비의 추가적 인 감소가 가능함을 예측 할 수 있다.

연구에서는 검사의 진단 가능성을 예측하기 위해서 정확 도라는 개념을 도입하여 검사방법에 대한 효용성을 판단하 였는데 복부 전산화 단층촬영의 상대적 우월성이 확인 되 었다.

상급종합병원 응급실에서는 중증질환의 배제와 환자의 신속, 정확한 분류와 진료가 최우선의 가치가 되어야 한다. 많은 환자를 진료 할 때 놓칠 수 있는 의료 과오를 방지하 기 위해서라도 결국 중증질환의 배제는 꼭 필요하며 이것 이 바로 의원, 종합병원과 차이라고 할 수 있을 것이다. 임 상 의사가 문진과 진찰, 진단검사, 의학적 검사 등으로 미 루어 보아 영상검사가 필요한 환자라고 판단을 했다라는 전제를 하고 본다면, 응급실에서 복부 CT촬영을 하지 않 더라도 결국에는 입원 또는 외래로 재내원 한 뒤 CT촬영 을 하는 경우가 대다수이며 앞서 언급한대로 단순 촬영 후 이상 결과의 유무와 관계없이 CT촬영은 증상의 원인을 밝 히거나 임상 의사의 진단적 자신감을 높여준다는 측면에서 필요하다고 할 수 있을 것이다.

2019년 1월1일부터 복지부에서는 응급실에 내원한 복통 환자의 경우 신속 정확한 선별진단을 위해 의심 단계에서 도 복부 CT 의 급여 적용을 한다고 발표했다. 그렇다면 '굳 이 조건 없이 복부 단순 촬영을 먼저 하여야 할까?' 라는 의문이 남는다. 예를 들어 임상 의사 진찰 후 판단에 따라, '이 환자는 기복증이나 다른 외과적 수술이나 즉각적인 처 치의 적응증이 될만한 단순 촬영상 소견이 없어서 다른 큰 문제는 없겠구나' 라는 판단 하에 먼저 의심되는 진단의 배 제를 위해 단순 촬영을 우선적으로 하는 경우라면 논란의
여지가 없겠으나, 단순히 영상검사가 필요하고 관행적으 로 단순촬영부터 하는 경우라면 이 문제는 다시 한번 고려 되어야 할 것 이라는 것이다. 실제 처방을 분석해보았을 때 상당수의 경우 복부 단순 촬영과 복부 전산화 단층촬영의 처방을 동시에 관행적으로 발행하는 경우가 있는 것 같았 으며 이러한 경우는 불필요한 의료비 상승의 원인이 되는 것이다. 특히 각 질환에 대한 의료비 상한을 두고 있는 포 괄수가제로의 전환이 이루어지는 시점에서 각 의료기관에 서 불필요한 의료비지출의 감소는 꼭 필요한 것이다.

환자 분류(triage)에 걸리는 시간에 대한 측면에서 보면 본 연구에서 나타난 결과만으로 언급하기에는 다소 비약적 인 면이 있을 수 있으나 간접적으로나마 영향을 미칠 수 있 을 것으로 생각되며 이는 나아가서 환자의 병원 재원 일수 에도 간접적으로 영향을 미칠 수 있다고 생각된다. 상급종 합병원의 시스템상 검사 하나를 수행하고 나서 그 결과 확 인을 위해서는 많은 시간이 소요된다 진료의 과정이라는 관 점에서 복부 단순 촬영과 복부 전산화 단층촬영 두 검사 모 두를 시행한 환자를 비교하였을 때 복부 전산화 단층 촬영 을 먼저 시행한 군에서 두 검사 사이의 시간간격이 짧았다. 이것은 환자 분류 시간이 짧아짐을 직접적으로 의미하는 것 으로 보기에는 무리가 있으나, 영상 진단을 할 때 CT를 먼 저 찍어서 검사 간 시간 간격을 줄이거나, CT가 꼭 필요할 것으로 판단되어 먼저 CT를 시행하였거나 또는 우연히 CT 를 먼저 찍었는데 병변이 확인이 된 경우에는 추가적으로 단순 촬영을 시행할 필요가 없게 되는 것이므로 환자 분류 시간 단축에 긍정적인 영향을 끼칠 수 있다고 생각된다.

방사선 노출에 대한 위험도 측면에서 $\mathrm{CT}$ 를 첫번째 영상 검사로 선택하는 것에 대해서 부담감을 갖고 있다. 하지만 이는 어디까지나 상급종합병원의 응급의료현실에 국한 된 것이며, 외래 환자와 같이 일반적인 경우에는 확대 적용될 수 없을 것이다. 그러나 연구는 상급종합병원 응급실에 내 원한 급성복증환자의 관리 및 진료에 있어서 임상 의사가 영상검사가 필요하다고 판단되었을 때의 경우이다. 이런 경우 단순촬영에서 문제가 없다고 하여도 즉각 퇴원에는 무리가 있는 경우가 많고 임상적으로 각 질환의 배제를 위 해서라도 추후 외래로 재내원을 하거나 입원을 해서 복부 
전산화 단층 촬영이 필요한 경우가 많다. 그리고 명백히 복 부 전산화 단층 촬영이 필요한 경우라 하더라도 관행적으로 단순 촬영을 먼저 하는 경우도 많은데 이러한 경우 오히려 습관적으로 시행하는 무의미한 복부 단순촬영으로 인해 환 자의 방사선 노출이 오히려 더 조장되도록 하는 면이 있다.

상급종합병원 응급실에 내원한 급성 복통 질환의 진단 또 는 배제를 위해서 복부 CT촬영이 필요하다면, 혹 불필요 한 단순 촬영은 하지 않는지 반드시 확인해보는 것이 중요 하며, 가능하면 불필요한 단순 촬영을 줄이는 것이 방사선 노출, 비용, 환자 분류에 들어가는 시간적 측면에서 도움이 될 수 있다고 생각된다.

본 연구에는 몇 가지 제한점이 있다.

첫번째, 대상 환자가 적고 기간이 짧아 평가내용을 전체 환자군으로 확대해석하기에 무리가 있을 수 있다. 병동 입 원환자나 외래환자에 대한 연구가 되지 않았다는 점도 있 다. 하지만 상급종합병원 응급실에서 불필요한 복부단순촬 영을 지양 하자는 것이 전제이므로 병동 입원 환자나 외래 환자의 복부단순촬영은 논외로 하였다.

두번째, 본 연구는 후향적인 연구로서 질환의 경과와 예 후, 정확한 가치 등에 대해서 평가하기 힘들었고 실제로 당 시 응급실에서 영상 검사를 시행하지 않고 돌아간 급성복 증환자에 대해서는 파악하기 어려웠다. 복부 단순촬영만 하고 퇴원하였던 경우 병변을 놓칠 확률 또는 오진율 등에 대한 자료가 수집될 수 없었다는 것이 한계가 될 수 있을 것이다. 다음 전향적 연구에서는 이 부분 확인이 필요 한 것 같다.

세번째, 비용적인 측면과 시간적인 측면 분석에 있어서 간접적인 지표들로 평가를 하다 보니 간접적으로 영향을 미칠 수 있다는 정도의 결론을 얻을 수 있었으나 직접적으 로 얼마나 큰 영향을 미치고 있는지에 대해서는 명확히 밝 힐 수가 없었다.

이러한 상기 제한점들에도 불구하고 앞으로는 전향적인 연구와 더 큰 규모의 연구를 통해 어떤 환자에서는 복부 $\mathrm{CT}$ 가 우선이 될 수 있는지, 어떤 환자에서는 CT의 진단적 우월성에도 불구하고 단순촬영을 먼저 시행하는 것이 응 급실내에서의 의사결정이나 비용-효과 면에서 타당한지,
그 적응증으로 삼을 만한 기준이 정립되어야 할 것이며 이 에 대한 연구가 필요하겠다. 영상검사의 가치와 상황에 따 른 적절성에 대해 고민함으로써 국가적, 병원적 차원에서 의 불필요한 의료비상승을 줄이고, 원활한 응급진료 및 환 자분류와 처치에 있어서 도움이 될 것으로 생각된다.

\section{V. 결론}

복부 CT의 진단적 정확도의 우월성은 익히 널리 알려진 사실이며 우리의 연구에서도 증명되었다. 비용, 환자 분류 까지 이루어지는 시간 단축의 의미에서 최초의 영상 검사 로 복부CT를 시행하는 것이 그에 맞는 환자 군에서는 도움 이 될 수 있다는 것을 알 수 있었다. 이는 나아가 건강보험 재정적인 측면과 각 병원 재정 입장에서도 도움이 될 수 있 을 것으로 생각되며 상급종합병원 응급의료현장에서 관행 적으로 의미 없이 시행하게 되는 복부 단순 촬영은 꼭 필요 한 경우가 아니라면 재고해 보는 것이 바람직하다고 생각 한다.

\section{VI. 참고문헌}

1. Sturman MF. Medical imaging in acute abdominal pain. Comprehensive Therapy. 1991;17:15-21.

2. Brewer BJ, Golden GT, Hitch DC, Rudolph LE, Wangensteen SL. Abdominal pain: an analysis of 1,000 consecutive cases in a university hospital setting. The American Journal of Surgery. 1976;131:219-23.

3. Anyanwu AC, Moalypour SM. Are abdominal radiographs still overutilized in the assessment of acute abdominal pain? A district general hospital audit. Journal of the Royal College of Surgeons of Edinburgh. 1998;43:267-70.

4. Ahn SH, Mayo-Smith WW, Murphy BL, Reinert SE, Cronan JJ. Acute nontraumatic abdominal pain in adult patients: abdominal radiogra- 
phy compared with CT evaluation. Radiology. 2002;225:159-65.

5. Chen JL, Dorfman GS, Li MC,Cronan JJ. Use of computed tomography scanning before and after sitting in an emergency department. Academic Radiology. 1996;8:678-82.

6. Rosen MP, Sands DZ, Longmaid HE, Reynolds KF, Wagner M, Raptopoulos V. Impact of abdominal $\mathrm{CT}$ on the management of patients presenting to the Emergency Department with acute abdominal pain. American Journal of Roentgenology. 2000;174:1391-6.

7. Raja AS, Mortele KJ, Hanson R, Sodickson AD, Zane R, Khorasani R. Abdominal imaging utilization in the emergency department: Trends over two decades. Emergency Medicine Journal. 2011;4:19.

8. Emergency medical sevice[internet]. Emergency medical sevice: 2018. Available from: http:// medicine.yonsei.ac.kr/class_subject/clinic_class/ emer/board/download.asp?gid=25\&cat_eng=/ class_subject/clinic_class/emer/board\&num $=467$

9. Naver knowledge dictionary. ECRS(Eliminate, Combine, Rearrange, Simplify). Availablefrom: http://terms. naver.com/entry.nhn?docId=2179135\&cid=51072\&categoryld $=51072$

10. McCaig LF, Nawar EW. National Hospital Ambulatory Medical Care Survey: 2004 emergency department summary. Advance Data 2006;23:1-29.

11. Flasar MH, Goldberg E. Acute abdominal pain. Medical Clinics of North America. 2006;90:481503.

12. Ronsen MP, Siewert B, Sands DZ, Bromberg R, Edlow J, Raptopoulos V. Value of abdominal CT in the emergency department for patients with abdominal pain. European Radiology. 2003;13:41824. 